\title{
Lignocellulosic Waste Pretreatment Solely via Biocatalysis as a Partial Simultaneous Lignino-Holocellulolysis Process
}

\author{
Justine Oma Angadam ${ }^{1}$, Seteno Karabo Obed Ntwampe ${ }^{2}$, Boredi Silas Chidi ${ }^{1, *}$, Jun Wei Lim ${ }^{3}$ (D) \\ and Vincent Ifeanyi Okudoh ${ }^{1}$ (D) \\ 1 Bioresource Engineering Research Group (BioERG), Cape Peninsula University of Technology, P.O. Box 652, \\ Cape Town 8000, South Africa; omajustine@gmail.com (J.O.A.); OkudohV@cput.ac.za (V.I.O.) \\ 2 School of Chemical and Minerals Engineering, North-West University Private Bag X1290, \\ Potchefstroom 2520, South Africa; karabo.ntwampe@nwu.ac.za \\ 3 Department of Fundamental and Applied Sciences, HICoE-Centre for Biofuel and Biochemical Research, \\ Institute of Self-Sustainable Building, Universiti Teknologi PETRONAS, Seri Iskandar 32610, Malaysia; \\ junwei.lim@utp.edu.my \\ * Correspondence: chidib@cput.ac.za
}

Citation: Angadam, J.O.; Ntwampe, S.K.O.; Chidi, B.S.; Lim, J.W.; Okudoh, V.I. Lignocellulosic Waste

Pretreatment Solely via Biocatalysis as a Partial Simultaneous Lignino-Holocellulolysis Process. Catalysts 2021, 11, 668. https:// doi.org/10.3390/catal11060668

Academic Editor: Zheng Guo

Received: 7 April 2021

Accepted: 17 May 2021

Published: 24 May 2021

Publisher's Note: MDPI stays neutral with regard to jurisdictional claims in published maps and institutional affiliations.

Copyright: ( $\odot 2021$ by the authors Licensee MDPI, Basel, Switzerland. This article is an open access article distributed under the terms and conditions of the Creative Commons Attribution (CC BY) license (https:// creativecommons.org/licenses/by/ $4.0 /)$.

\begin{abstract}
Human endeavors generate a significant quantity of bio-waste, even lignocellulosic waste, due to rapid industrialization and urbanization, and can cause pollution to aquatic ecosystems, and contribute to detrimental animal and human health because of the toxicity of consequent hydrolysis products. This paper contributes to a new understanding of the lignocellulosic waste bio-pretreatment process from a literature review, which can provide better biorefinery operational outcomes. The simultaneous partial biological lignin, cellulose and hemicellulose lysis, i.e., simultaneous semi-lignino-holocellulolysis, is aimed at suggesting that when ligninolysis ensues, holocellulolysis is simultaneously performed for milled lignocellulosic waste instead of having a sequential process of initial ligninolysis and subsequent holocellulolysis as is currently the norm. It is presumed that such a process can be solely performed by digestive enzyme cocktails from the monkey cups of species such as Nepenthes, white and brown rot fungi, and some plant exudates. From the literature review, it was evident that the pretreatment of milled lignocellulosic waste is largely incomplete, and ligninolysis including holocellulolysis ensues simultaneously when the waste is milled. It is further proposed that lignocellulosic waste pretreatment can be facilitated using an environmentally friendly approach solely using biological means. For such a process to be understood and applied on an industrial scale, an interdisciplinary approach using process engineering and microbiology techniques is required.
\end{abstract}

Keywords: lignocellulosic waste; cellulolysis; hemicellulolysis; ligninolysis; nepenthes species; plant exudates

\section{Introduction}

Environmental pollution by lignocellulosic waste dumped into the environment by various processing industries has been acknowledged to be toxic [1], and thus can have a negative effect on the earth's ecology and human health. Therefore, the excessive landfilling of this type of waste is discouraged. Lignocellulosic waste generates acidic leachate with phenols being one of the major toxicants that poisons water bodies [2]. Such a leachate was determined to have a negative effect on several aquatic organisms [3,4]. Although there are other industries, i.e., petroleum refineries, gas and coking industries, pharmaceutical manufacturers, explosives/munition manufactures, phenol-formaldehyde resin manufactures, plastic and varnish industries among others [5] producing phenol containing waste, the focus of this perspective was on lignocellulosic waste.

Generally, 1.77-2.4 Gt of waste from cereals, roots and tubers, oilseeds, and fruit and vegetables are produced globally annually [6] and most can be classified as lignocellulosic 
waste with a significant cellulose, hemicellulose and lignin content [7]. Cellulose, hemicellulose and lignin content in lignocellulosic waste varies in most lignocellulosic materials. Research has successfully demonstrated that lignocellulosic waste can be treated using several techniques [8-10], with landfilling being one of the oldest disposal methods; however, it produces greenhouse gasses in the form of carbon, which is released as $\mathrm{CH}_{4}$, which further pollutes the environment [11]. To further understand lignocellulosic waste, and to mitigate its influence on the environment for repurposing and cleaner disposal, understanding of its composition and currently available pretreatment methods, i.e., pre-treatment strategies such as physical, chemical, biological and physico-chemical [12], must be further developed.

Overall, it is difficult for enzymatic hydrolysis to decouple the lignin in lignocellulosic waste into its primary components due to the bond structure of lignin-cellulosehemicellulose. This limits the delignification efficiency via natural ligninolysis of the lignocellulosic waste [13]; however, lignin can be degraded using a different physico-chemical methods. These methods cannot be classified as environmentally benign. However, they boost the enzymatic hydrolysis of residual holocelluloses, i.e., cellulose and hemicellulose, in a sequential process whereby the lignocellulosic waste is initially physico-chemically pretreated and subsequently hydrolyzed using cellulases from different species, i.e., Aspergillus, Penicillium and Trichoderma spp. [14]. Some of these pretreatment processes are ineffective in delignifying the firm organization of lignin.

However, peroxidases from fungi such as Phanerochaete chrysosporium and have been proven to facilitate ligninolysis and thus biodegrade the rigid structure of lignin [15]. This provides for biological ligninolysis, exposing the holocellulosic matrix of the biomass to hydrolysis, and reducing the need for chemical solution usage in lignocellulosic waste pretreatment [16]. These peroxidases have been produced in high volumes using membrane bioreactor technology [17]. It is therefore feasible to introduce a biological pretreatment of lignin containing lignocellulosic waste, in a process optimized for ligninolysis to expose holocellulosic components to hydrolysis, i.e., holocellulolysis. In fact, lignocellulosic waste is predominantly made up of irregular $\beta-1.4$ glycosidic bonds. These bonds can be lysed by cellulases and $\beta-1.3-\beta-1.4$ glucanases from different microorganisms, e.g., Chaetomium sp. [18] and some Nepenthes specie enzymes, i.e., enzymes produced by $N$. alata [19] and N. ventrata [20]. Furthermore, it was previously reported that there is evidence of leaf litter decomposition and mineralization in the cups of N. ampullaria [21]. The use of pitcher monkey cup extracts for lignocellulose waste pretreatment was also reported elsewhere [22]. Rottloff et al. [23] reported that Nepenthes species have evolved an arsenal of enzymes and the digestive fluids is composed of proteins, including hydrolytic enzymes, some of which can be useful in lignocellulose waste pretreatment. The availability and cultivation of species such as those of Nepenthes can be achieved using a hydroponic growth method [24] to mitigate against regional unavailability and for large-scale digestive juice production.

Consequently, the absolute hydrolysis of lignocellulosic waste into fermentable sugars requires a cocktail of oxidative and hydrolytic enzymes. Although researchers have used cellulases for years to ease the pretreatment process post physico-chemical treatment, cellulases are not adequate to complete ligninolysis and holocellulolysis simultaneously. Moreover, as cellulose is also usually intricated in hemicellulose, i.e., cellulose is entrapped in hemicellulose, a significantly abundant natural polymer found in lignocellulosic waste. Furthermore, hemicellulose is constituted by xylan with further ester bonds bound to lignin [25]. Its hydrolysis involves diverse conditions and numerous methods to competently hydrolyze it into fermentable monomers [26]. The primary constituent of hemicellulose, xylan, can be hydrolyzed by a cocktail of enzymes $[13,27]$ to decouple any residual bonds. These are enzymes produced as exudates or extracellular bioproducts from a variety of microorganisms (see Table 1), which can be used to lyse lignocellulosic waste. This can be effected via beneficiation and further sustainable utilization of obtained hydrolysates for the production of added-value products. Therefore, the simultaneous 
partial biological delignification (ligninolysis) and holocellulose decoupling, (holocellulolysis), herein referred to as semi-lignino-holocellulolysis can describe mechanisms associated with enzymatic ligninolysis, hemicelluloses and celluloses lysis in lignocellulosic waste without the use of chemical pretreatment. Overall, in lignocellulosic waste pretreatment, some lignin and holocellulose remains intact (see Table 2, highlighting other pretreatment methods and their products) even when an alkali pretreatment is used; a method previously determined to increase cellulose digestibility by enhancing lignin solubilization [28]. Thus the notion of semi-ligninolysis and holocellulolysis is valid.

Overall, for the progress of an environmental friendly set-up, delignification (ligninolysis) is warranted using appropriate plant and microbial oxidative/digestive enzymes. The latter can be used as one of the key processes that are appropriate to limit environmental contamination by the lignocellulose waste, while efficiently ligninolyzing the recalcitrant lignin structure to uncover holocelluloses [29] for simultaneous ligninolysis and holocellulolysis. This was initially reported in Dlangamandla et al. [22] and Angadam et al. [16], with some of the digestive enzymes reported in Hasan et al. [30] being shown to support semi-lignino-holocellulolysis; however, feasibility studies for implementation on an industrial scale are ongoing. Even the assessment of oxidation-reduction potential and acidic strength evaluations of symbiont extracts from the Nepenthes sp. pods clearly indicate a high potential to facilitate oxi-reductive reactions and are very compatible to even those of the commonly used dilute (1\%) sulphuric acid solution (see Table 3), which is preferred, to increase cellulose accessibility by weakening the hemicellulose bonds. Overall, the use for plant and microbial enzymes including extracts will require a physical pretreatment step, such as milling of the lignocellulose waste to increase the overall biocatalysis area and to condition the lignocellulosic waste for enhanced lysis.

Overall, research has proven that commonly used lignocellulosic waste pretreatment processes such as hot water, dilute sulphuric acid, and alkali methods including cellulases, are being encouraged and are considered to be inexpensive, suitable, and effective. The use of harsh delignification methods, such as chemical treatment methods, does affect subsequent cellulase/enzyme facilitated hydrolysis to produce fermentable sugars [31]. This can be categorized as inappropriate for a green chemistry approach for biorefinery development due to the production of residual toxicants such as furfural, phenolic compounds, etc., all of which affect fermentation. These residual toxicants can affect enzymatic hydrolysis and microbial action towards hydrolysate conversion during fermentation due to their toxicity [32]. Therefore, in summary, this paper contributes to a new understanding that lignocellulosic waste pretreatment is largely a partial and simultaneous lignino-holocellulolysis process, even when chemical pretreatments are used. Evidently, this process can be supported solely by a cocktail of enzymes from a variety of plant and microbial sources. Previously, Dlangamandla et al. [22] also demonstrated total phenolic compound reduction, i.e., $<3 \mathrm{~g} / \mathrm{Kg}$, in hydrolysates solely pretreated with digestive juices of $\mathrm{N}$. mirabilis; albeit with $2.6 \mathrm{~g} / \mathrm{Kg}$ reducible sugars from mixed lignocellulose waste using non-optimum conditions. 
Table 1. Components in lignocellulosic waste, processes and a few examples of enzymes and their source associated with the waste component lysis.

\begin{tabular}{|c|c|c|c|c|}
\hline $\begin{array}{l}\text { Components in } \\
\text { Lignocellulosic } \\
\text { Waste }\end{array}$ & Process & Enzymes & $\begin{array}{l}\text { Source of Enzymes in Plants } \\
\text { and/or Organisms }\end{array}$ & Reference \\
\hline Lignin & $\begin{array}{l}\text { Delignification } \\
\text { (ligninolysis) }\end{array}$ & $\begin{array}{c}\text { Lignin peroxidase, } \\
\text { Manganese peroxidase, } \\
\text { Laccase }\end{array}$ & $\begin{array}{c}\text { Phanerochaete chrysosporium, } \\
\text { Phaseolus vulgaris, } \\
\text { Ganoderma lucidum IBL-05, } \\
\text { Trametes villosa }\end{array}$ & {$[16,33-35]$} \\
\hline Cellulose & Cellulolysis & $\begin{array}{l}\beta \text {-glucosidases } \\
\text { Cellulases }\end{array}$ & $\begin{array}{c}\text { Bacillus sonorensis BD92 } \\
\text { N. mirabilis }\end{array}$ & \\
\hline & & Endo-glucanase & Bacillus subtilis CBS31 & \\
\hline Hemicellulose & (holocellulolysis) & $\begin{array}{c}\text { Exo } \beta-1.3-\beta-1.4 \text {-glucanase } \\
\text { Acetyl xylan esterase }\end{array}$ & $\begin{array}{c}\text { Thielavia terrestris Co3Bag1 } \\
\text { Alkalibacillus favidus }\end{array}$ & [36-45] \\
\hline 1 1етіне & 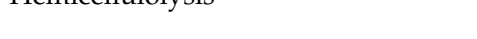 & Cellulase-free xylanase & Paenibacillus sp. N1 & \\
\hline & & Arabinofuranosidase & Streptomyces lividus & \\
\hline & & $\begin{array}{c}\alpha \text {-arabinofuranosidase, } \\
\text { feruloyl esterase }\end{array}$ & $\begin{array}{c}\text { Aspergillus hortai CRM1919, } \\
\text { Lactobacillus crispatus }\end{array}$ & \\
\hline
\end{tabular}

Table 2. Evidence of partial lignin-hemicellulose-cellulose lysis during lignocellulose waste pretreatment using alkaline pretreatments (Basis: $35 \mathrm{~g}$ of waste feedstock) [46].

\begin{tabular}{ccc}
\hline Lignocellulose Waste Component & Concentration in Untreated Waste (\%) & Concentration in Pretreated Waste (\%) \\
\hline Cellulose & $43.4-35.9$ & $42.8-32.4$ \\
Hemicellulose & $29.1-18.7$ & $23.1-10.7$ \\
Lignin & $30.1-29.0$ & $25.8-4.1$ \\
\hline
\end{tabular}

Other by-product constituents in lignocellulose waste from different pretreatment methods [47]. Acid-based methods: aliphatic carboxylic acids, phenylic compounds, furans; hydrothermal processing: acetic acid, furan aldehydes; mild alkaline methods: acetic acid, hydroxy acids, dicarboxylic acids, phenolic compounds; oxidative methods: aldonic and aldaric acids, furoic acid, phenolic acids, acetic acid [47].

Table 3. Direct comparison of dilute (1\% v/v) sulphuric acid solution (Grauer 1991) to N. mirabilis pod extracts [16,22].

\begin{tabular}{cccc}
\hline $\begin{array}{c}\text { Solution/Extract } \\
\text { (Characteristics) }\end{array}$ & Oxidation Reduction Potential (mV) & pH & Acid Strength \\
\hline $\begin{array}{c}\text { N. mirabilis digestives pod extracts (contains } \\
\text { symbionts and a cocktail of enzymes known for } \\
\text { lignino-holocellulolysis) }\end{array}$ & $510-526$ & $1.8-2.2$ & Strong \\
\hline $\begin{array}{c}\text { Sulphuric acid } \\
(1 \% v / v, \text { free of symbionts and enzymes) }\end{array}$ & 354.2 & 0.7 & Strong \\
\hline
\end{tabular}

\section{Current Beneficiation of Lignocellulosic Waste Using Different Pretreatment Techniques}

Pretreating lignocellulosic waste is a mandatory phase to accomplish hydrolysis of biorefinery feedstock aimed at producing value-added products, i.e., fermentable sugar (highest release of reducing sugars, i.e., up to $10.70 \pm 0.14 \mathrm{~g} / \mathrm{Kg}$ biomass of glucose and $12.41 \pm 0.34 \mathrm{~g} / \mathrm{Kg}$ biomass of xylose from lignocellulose waste [41]), in biorefinery processes [48]. Pretreatment facilitates ligninolysis and consequently, uncovering holocelluloses for the subsequent successful hydrolysis of the lignocellulosic waste with negligible energy intake, to accomplish the outmost fermentable sugar extraction $[49,50]$. Numerous techniques, such as hot water, dilute sulphuric etc., have been utilized to eliminate the recalcitrant lignin in lignocellulosic waste focusing on the feedstock being beneficiated to mitigate environmental pollution. Several lignocellulosic waste pretreatment approaches have been impractical and wasteful due to some technical challenges, which include the low yield and the formation of inhibitory by-products, e.g., furfural (up to $34.5 \mathrm{~g} / \mathrm{Kg}$ ), 
hydroxymethyl furfural (up to $29.5 \mathrm{~g} / \mathrm{Kg}$ ), total phenolics compounds (up to $4.1 \mathrm{~g} / \mathrm{Kg}$ ) and weak organic acids (up to $114.9 \mathrm{~g} / \mathrm{Kg}$ ), including total furans (up to $34.5 \mathrm{~g} / \mathrm{Kg}$ ) [51,52]. The processes involved bio-physico-chemical ligninolysis and holocellulolysis of lignocellulosic waste include physical (milling), thermal (hot water), chemical (dilute acid, caustic) and microbial-based processes [53,54]. Formation of by-product toxicants is usually observed during dilute acid and alkaline pretreatment as lignin is being partially degraded [48,51]; however, it is still assumed to be the ideal pretreatment method for an industrialized approach to date. Some common types of acid used in pretreating lignocellulosic waste from agriculture and forestry include dilute sulphuric $\left(\mathrm{H}_{2} \mathrm{SO}_{4}\right)$, phosphoric $\left(\mathrm{H}_{3} \mathrm{PO}_{4}\right)$, hydrochloric $(\mathrm{HCl})$, and nitric $\left(\mathrm{HNO}_{3}\right)$ acid [55]. Nonetheless, it has been proven that dilute sulphuric acid is the best and is frequently used in chemo-ligninolysis because of its suitability for degrading a widespread selection of lignocellulosic waste, even in a mixed form [56,57].

The alkaline (corrosive) pretreatment methods including those using sodium hydroxide $(\mathrm{NaOH})$ solutions, are commonly known for lignin lysis. Some other alkaline-based methods include ammonia fiber explosion (AFEX), ammonia recycle percolation (ARP), lime $\left[\mathrm{Ca}(\mathrm{OH})_{2}\right]$ and aqueous ammonia soaking (AAS), using chemical generally observed to be readily available, cheap and provide for consistent lignocellulosic waste pre-treatment. Alkaline pretreatment techniques are dynamic at low heat and pressure; however, they require a large quantity of water, while using less energy when compared to dilute acid pretreatment, consequently lowering enzyme loading, which is essential for hydrolysis and hence can lower the general operational costs of a biorefinery [58].

\section{Ligninolysis of Lignocellulosic Waste: Physico-Chemical and Biological Methods}

Ligninolysis describes the decoupling of lignin from lignocellulosic waste through ligninolysis, which is achieved initially by milling/grinding to reduce the waste crystallinity [59]. Chemical oxidation or acidification to reduce lignin-holocellulose bond strength by disrupting aryl-ether, C-C and xylosidic links and breaking of acetyl ester linkages [8] is a process which can also be achieved solely by biological means. This includes the decomposition of ether bonds [10], subsequent to the decoupling of phenolic/nonphenolic structures within the lignocellulosic waste [60]. All these types of ligninolysis can be described as physico-chemi-ligninolysis, as they involve physical and chemical means of lignin lysis, for which an alternative technological approach is needed for the process to be environmentally benign. Overall, this means a biological approach.

The act of enzymatic hydrolysis of lignin can be described as ligninolysis. Filamentous fungi and other microorganisms, including those in the family of Basidiomycetes such as white rot fungi (WRF) for ligninolysis, and brown rot fungi (BRF) for holocellulolysis, have proven to be the most commonly known natural matter disintegrators for the breaking down of lignin [61], in particular lignocellulosic waste. WRF-facilitated ligninolysis is principally the hydrolysis of lignin with insignificant holocellulose breakdown [62]. The major enzymes involved in such ligninolysis include Lignin peroxidases (LiPs), Manganese peroxidases (MnPs) and Laccase (Lac) produced by a variety of fungi (e.g., Phanerochaete chrysosporium, Pleurotus ostreatus (Jacq.), Pleurotus kumm (MCC16)) under nutrient-limited conditions, similar to BRF, such as Chaetomium sp., Ceratocystis sp., and Kretzschmaria deusta, which produce enzymes such as cellulases, laccase, and lignin peroxidases, all known to solubilize lignino-holocelluloses [18]. However, there are uncertainties as to whether these are the sole streamlined bio-delignifiers and bio-holocellulolisers of lignocellulosic waste. Although lignin is resistant because of its low porosity, and thus protects the energy-rich holocellulose of plants cell walls, it can be solubilized using the digestive extracts of plants, such as those of Nepenthes sp., in combination with cellulases releasing coniferyl, synapyl, and $p$-coumaryl alcohols, including ferulic acid, glucuronic acid, and the acetyl group [63] (see Figure 1(a1,a2)). 


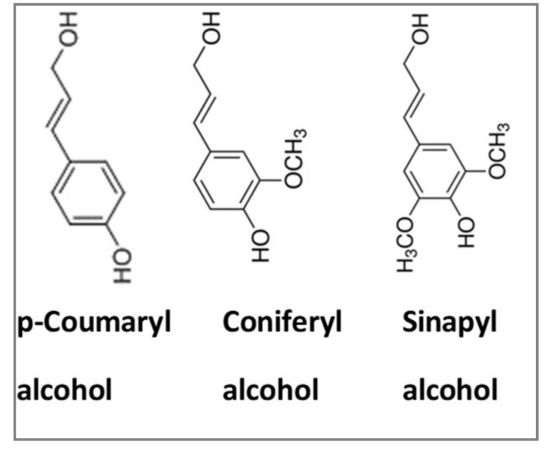

(a1)

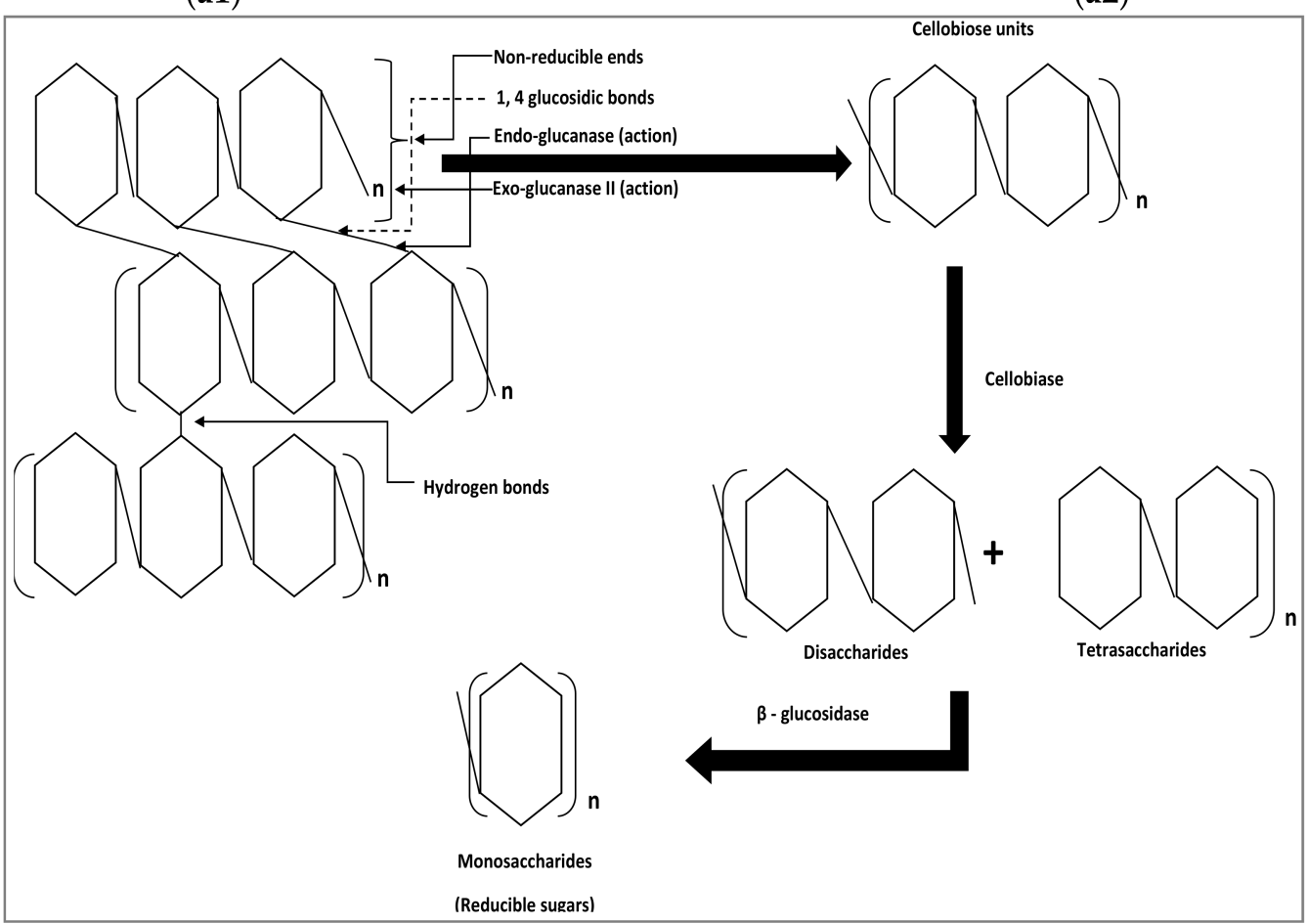

(b)

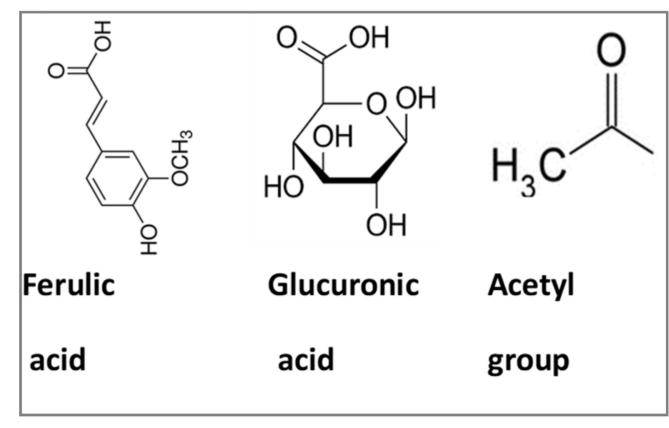

(a2) 


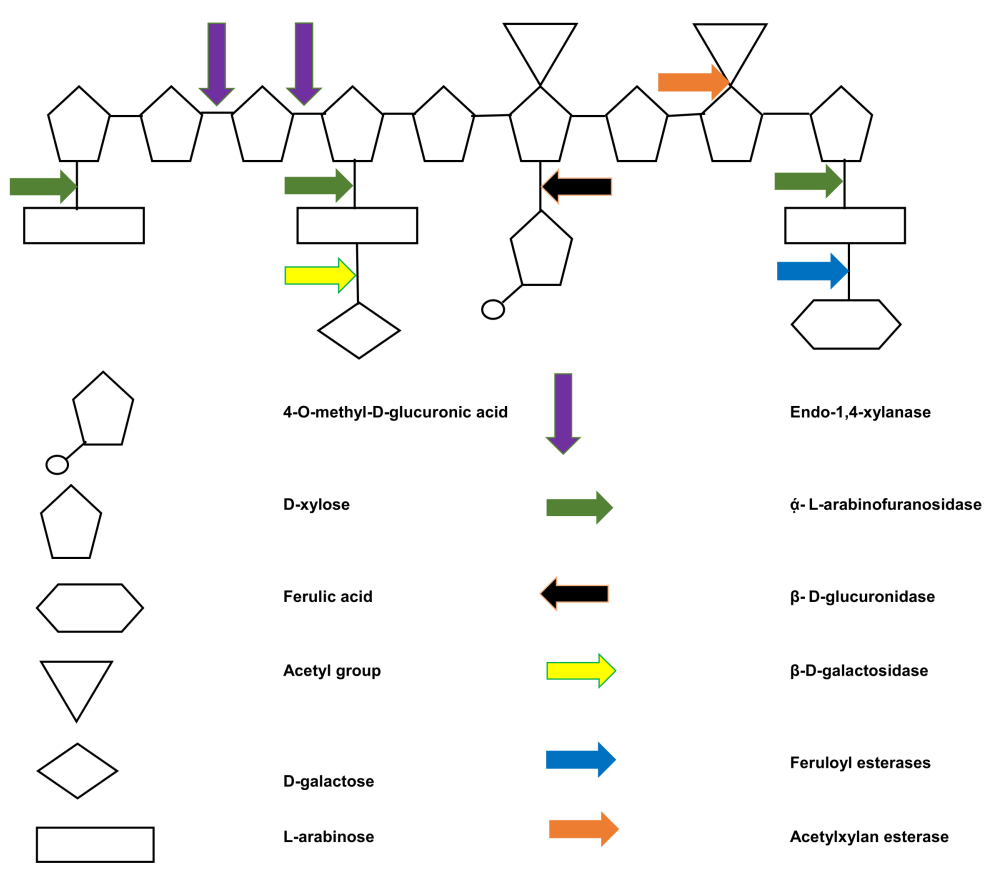

(c)

Figure 1. Molecular structures of products of (a1) ligninolysis and (a2) holocellulolysis; (b) process of cellulolysis including enzymes at each biocatalysis step, and (c) enzyme action site involvement in hemicellulolysis including end-products.

\section{Holocellulolysis of Lignocellulosic Waste}

Research has shown that when lignocellulosic waste is pretreated either by physical, chemical, or biological methods, lignin, and holocelluloses, are partially lysed simultaneously. The main enzymes responsible for the breaking down of the crystalline and amorphous structure of cellulose are known as Endo-glucanase (EGs) and Exo-glucanase II (CBHs-II). The endo-glucanase decomposes the 1,4- $\beta$-glycosidic bonds, while the CBHs decouples the non-reducible ends of crystalline structure of the cellulose. When the EGs and CBHs act on cellulose, an amorphous structure is produced, which is catalyzed by cellubiase to produce certain products. These are cellubiose units which are further biotransformed into di- and tetra-saccharides. Finally, $\beta$-glycosidase reduces these sugars into monosaccharides. This scenario is diagrammatically represented in Figure 1b. Unlike cellulose, hemicellulose (xylan) is more complex and its lysis requires more specific and multiple enzymes. Endo-xylanase hydrolyzes the main chains of xylan, and $\beta$-xylan esterase reduces xylooligosaccharides into xylose, with $\alpha$-arabinofuranosidase and $\alpha$-glucuronidase acting on the xylan backbone for the removal of arabinose and 4-o-methyl glucuronic acid. The esterases thereafter reduce the acetyl substitutions on the xylose, while feruloyl esterases hydrolyse the ester bonds located between arabinose substitutions and ferulic acid. Furthermore, feruloyl esterases also makes it easier to decouple hemicellulose in lignocellulosic waste. Figure 1c illustrates the hemicellulose structure and individual enzyme types, including actions on individual bonds, to release a variety of reducible sugars and other byproducts. As illustrated in Table 1, a large number of these enzymes can be sourced from plant or microbial sources.

\section{Simultaneous Partial Biological Ligninolysis and Holocellulolysis}

\subsection{Perspective on Semi-Delignino-Holocellulolysis}

Lignin is responsible for the rigidity and the nature of plants including lignocellulosic waste. The mash structure of the lignin contains surface pores, which are amorphous in nature (see Figure 2a), and consist of irregularly based carbon molecules. This explains why 
some plants are able to secret plant exudates externally to the bark of a tree, some of which are used as a defense mechanism. This enables organisms such as WRF, which produces lignin and manganese peroxidases, including laccase, to initially lyse this amorphous region to start the ligninolysis of the lignin barrier directly [15]. Similarly, BRF exploits the amorphous regions in lignocellulosic waste by initially producing oxidation reactive species to further weaken the amorphous regions of the lignocellulosic waste, subsequent to holocellulolysis via a cocktail of glycoside hydrolases, leaving the lignin residue (see Figure 2a). Additionally, the simultaneous, i.e., co-current, ligninolysis and holocellulolysis can take place during the decomposition of such lignocellulosic waste in a symbiotic environment, implying that the hydrolysate will be richer in both lignin products and holocellulose constituents, such as mono- and tetra-saccharides. Therefore, the classification of this phenomenon, i.e., simultaneous ligninolysis and holocellulolysis, can be termed lignino-holocellulolysis. Overall, during pretreatment of lignocellulosic waste, some residual lignin and holocellulose are present in the residue, which indicates partial, i.e., semi, pretreatment. It is therefore logical to have the classification 'semi-lignino-holocellulolysis. Lignin and holocellulose can consequently be partially degraded simultaneously because as lignin is recalcitrant, some acidic extracellular bio-products can directly act on the lignin structure. For example, the production of $\mathrm{LiP}$ and $\mathrm{MnP}$ from P. chrysosporium was shown to reduce the $\mathrm{pH}$ of the environment in which the organism was grown while the oxidativereduction potential increased [17]. This would thereafter enable the hydrolases and other enzymes to biocatalytically lyse holocelluloses, while ligninolysis ensues. This can be optimized and effectively used to pretreat even mixed lignocellulosic waste. Some plant digestion extracts, i.e., those of $N$. mirabilis, have a high acidic strength and can therefore solubilize some lignin components [21], weakening their structure such that cellulases can easily penetrate the holocellulose [22]. This type of reaction is irreversible and is assumed to follow multiple bioreactions in parallel, as illustrated in Figure 2c, and not in series as shown in Figure 2b [9].

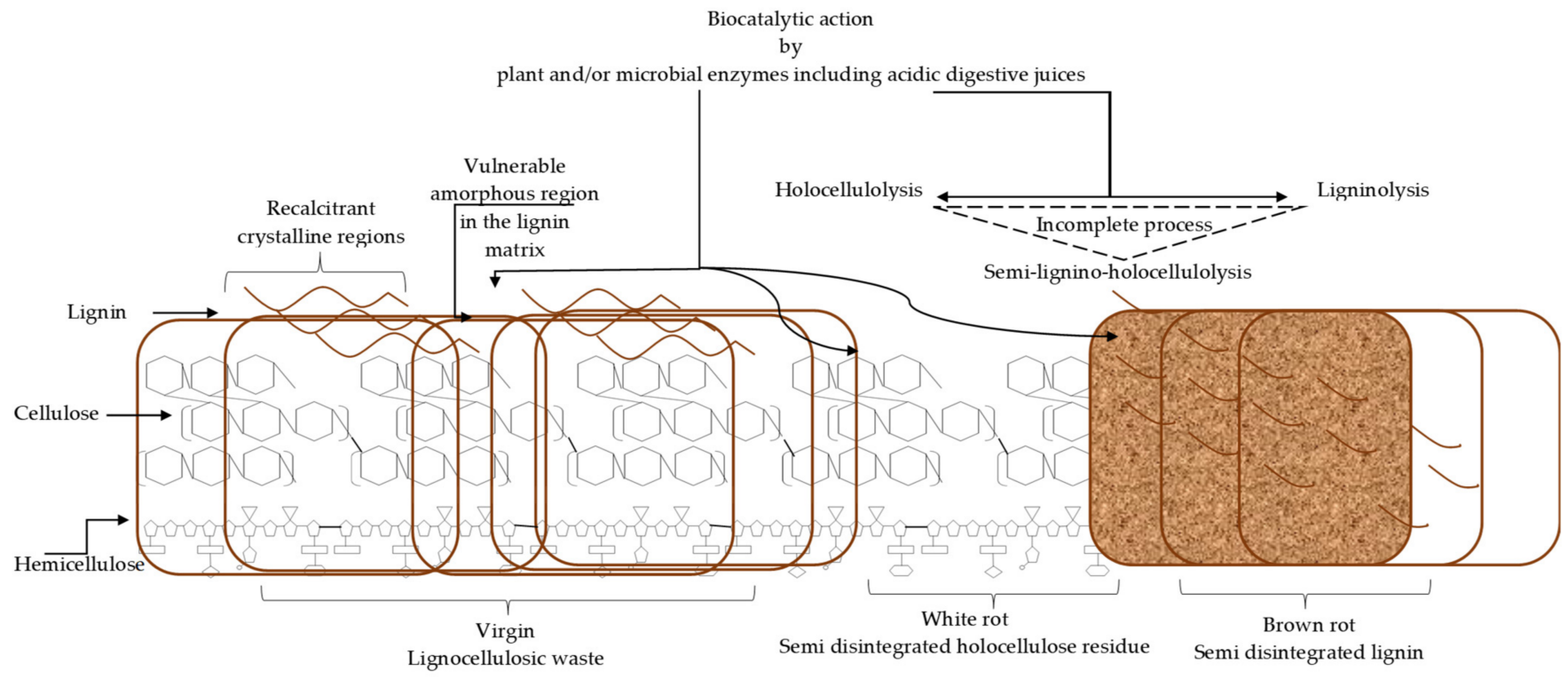

(a)

Figure 2. Cont. 


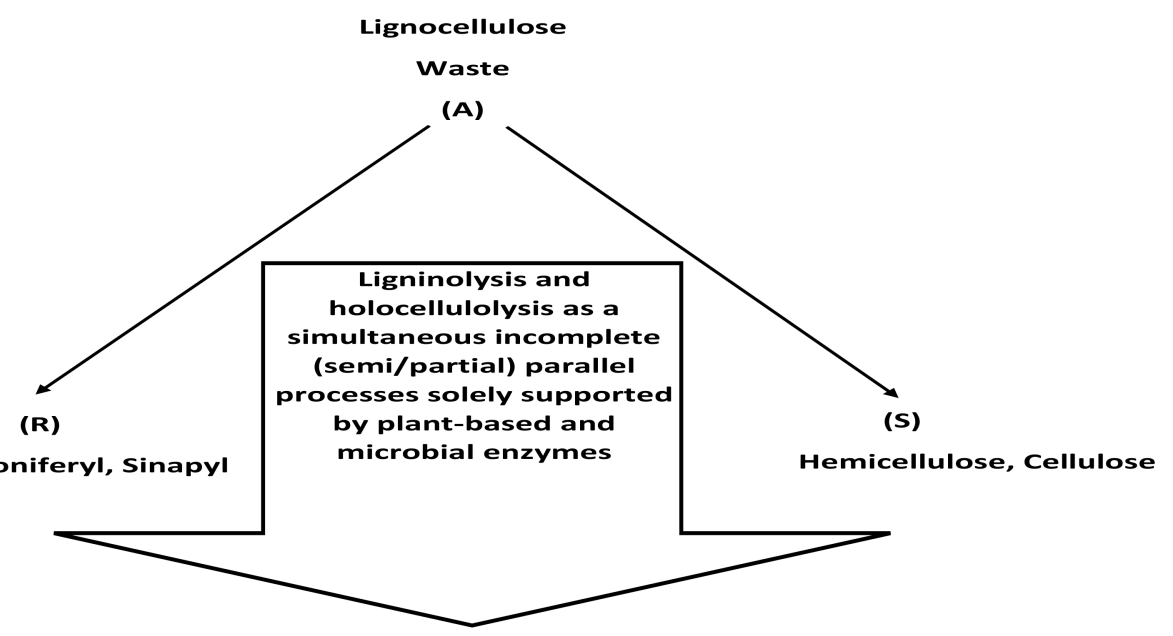

(b)

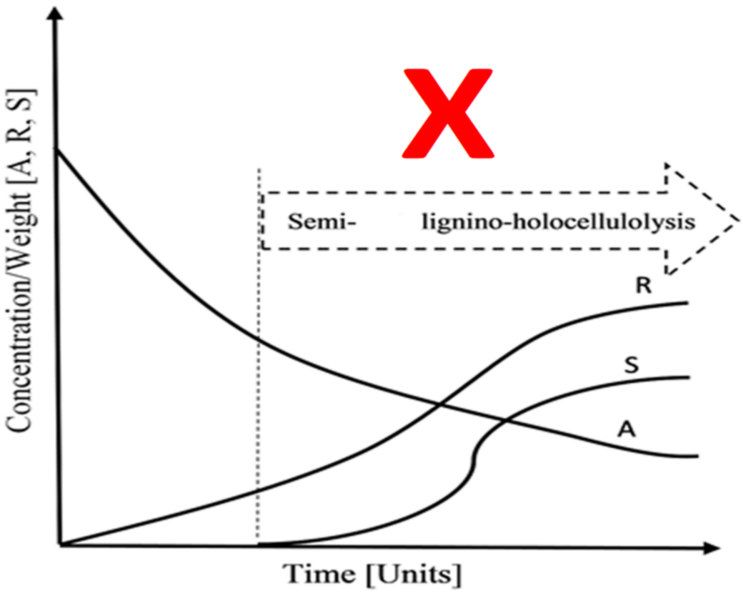

(c1)

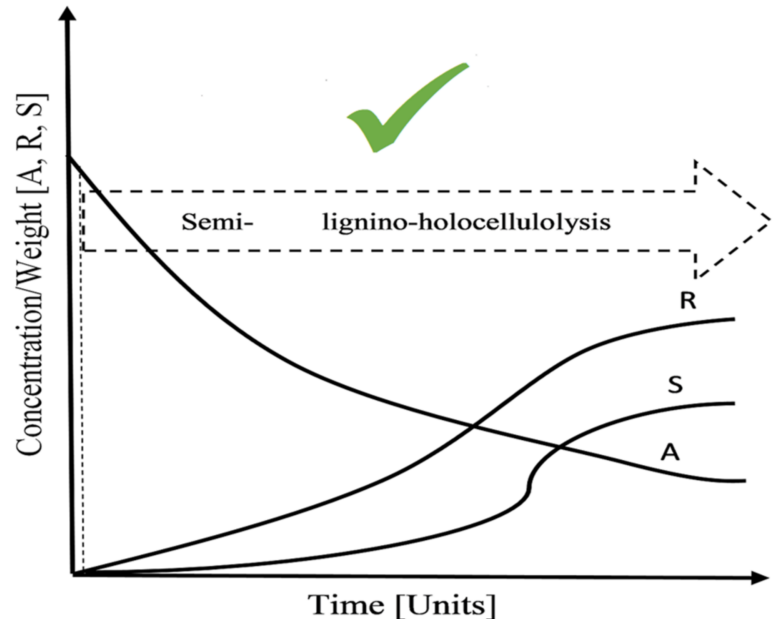

(c2)

Figure 2. (a) Illustration of the rigid and amorphous regions of lignocellulosic waste and how plant-based or microbial enzymes will facilitate semi-lignino-holocellulolysis; (b) depiction of the hydrolysis of lignocellulose waste (A) into primary products, R (alcohols)-for ligninolysis and S (cellulose/hemicellulose) for holocellulolysis simultaneously; (c1) demonstration of semi-lignino-holocellulolysis as irreversible reactions in series; and (c2) demonstration of simultaneous semi-ligninoholocellulolysis as irreversible first order reactions in parallel.

\subsection{Plant Exudates and Enzyme Cocktails for Semi-Lignino-Holocellulolysis of Lignocellulosic Waste}

Plant exudates contain bioactive compounds such as amylases, invertases, phosphatases, proteases, and polygalacturonases, which include certain amino acids, organic acids, reducible sugars, phenolics, flavonoids, etc. Furthermore, studies have shown that plant extracts from plants of the genus Nepenthes contains $\beta$-glucosidases, xylanases and carboxylesterases, proteases, ribonucleases, nucleases, phosphatase hydrolasse, esterases, ribonucleases, and amylases, which are used to digest insects trapped in the fluid inside monkey cups [64]. These fluids are acidic and have a $\mathrm{pH}$ between 1.5 to 6 , depending on the species [22]. A lot still needs to be researched regarding the bioactive ingredients found in carnivorous plant cocktails [65]. There are some common enzymes found in both plant exudates and in Nepenthes sp. that can be useful in the delignification of lignocellulosic waste and in particular, the lysis of holocellulose [66,67]. Overall, alternatives for lignino-holocellulolysis in a process in which there is minimal use of chemicals or high temperature and pressure will provide for a better, environmentally benign process that 
will have a minimal impact on the environment, whilst providing for process sustainability and integration.

\section{Future Perspective, Mitigation of Limitations, and Economic Impact}

Future perspective: from the preceding studies, it appears that the various techniques that have been exploited in the quest to pretreat bio-waste for the extraction of value-added products are posing newer challenges. These include the production of inhibitory products such as phenolic compounds, furfural, organic weak acids, etc. [68] Although chemical pretreatments produce more inhibitors such as phenolic compounds, the presence of lipases and esterases in pitcher digestive juices [69] for lignin-holocellulolysis is advantageous, as these enzymes have been determined to hydrolyze some phenolic compounds [70]. The use of acids to pretreat bio-waste such as lignocellulosic waste can therefore be expensive, and it is not eco-friendly. The future lies with the sole use of plant-based digestive extracts and microorganism-based enzymes under optimal conditions, as some plant digestive enzymes have been shown even to have similar characteristics to those of certain dilute strong acids, albeit with the added advantage of having active enzymes and symbionts within such extracts.

Mitigation of limitations: biological pretreatment of lignocellulosic waste, using, for example, N. mirabilis digestive extracts, can be effective, and the carboxylesterases that are available in the plant extracts can assist in reducing the inhibitory bio-products produced during pretreatment of bio-waste, such as lignocellulosic waste [22]. The use of such plant extracts in the pretreatment of lignocellulosic waste will limit environmental harm in any process developed. However, a further development of this strategy is required.

Economic impact: in developed countries, the use of renewables is rising rapidly [71], and therein lie opportunities for developing countries to use their locally available biomass for value-added product manufacturing. For lignocellulose waste beneficiation, industries can use a well-defined ecological criterion, and bring savings in terms of emissions trading among many other economic benefits as reported as elsewhere [71]. Recently, Angadam [16] reported on the pretreatment, i.e., using N. mirabilis digestive juices, of lignocellulosic pomace as a waste for high reducible sugar production. This is just one of the examples which can be used for economic benefits while taking into account environmental safety. Furthermore, the exploitation of the knowledge and understanding of the idea of lignocellulosic waste biological pretreatment in which partial simultaneous lignino-holocellulolysis ensues, will therefore affect reactor system prototype designs [72].

\section{Conclusions}

Lignocellulosic waste is made up of holocelluloses that are bonded together in a lignin matrix. This type of bio-waste can be used in biorefineries for the production of value-added products such as bio-alcohols by using bio-physico-chemical pretreatment methods and enzymes from plants and microorganisms. Holocellulose hydrolysis can be achieved solely by a cocktail of enzymes such as endoglucanases, cellobiohydrolases, and $\beta$ glucosidases enzymes. These can lyse the lignocellulosic waste via lysis of the hemicellulose by decoupling of $\beta-1,4$ D-xylose polymer bonds by endo 1,4- $\beta$-xylanase or endoxylanase, $1,4-\beta$-xylan esterases, $\alpha$-1-arabinofuranosidases, and $\alpha$-glucuronidases, etc. This occurs in a process whereby there is a concurrent semi-biological deligninolysis and holocellulolysis using a process herein termed semi-lignino-holocellulolysis. To achieve a higher efficacy of semi-lignino-holocellulolysis, ligninolysis accomplished by milling/grinding to reduce the lignocellulosic waste crystallinity has to be the primary step, as this will disrupt linkages within the waste matrix for effective hydrolysis. In general, there are some enzymes found both in plant exudates, e.g., Nepenthes species, which are microbially produced extracellularly and can be used for semi-lignino-holocellulolysis of lignocellulosic waste to allow an environmentally benign process, and to mitigate against the use of chemicals, heat, and pressurized systems, to which this paper contributes as a necessary discussion for biorefinery development. 
Author Contributions: Conceptualization, J.O.A., S.K.O.N., B.S.C., J.W.L. and V.I.O.; writingoriginal draft preparation, J.O.A.; writing-review and initial editing, J.O.A., S.K.O.N., B.S.C., J.W.L. and V.I.O.; supervision, S.K.O.N., B.S.C., J.W.L. and V.I.O.; project administration, S.K.O.N. and V.I.O.; funding acquisition, S.K.O.N. and V.I.O. All authors have read and agreed to the published version of the manuscript.

Funding: This research was funded by the National Research Foundation of South Africa as well as the CPUT University Research Fund (URF RK16), and the support of the CPUT Vice-Chancellor's Prestigious Award is also acknowledged.

Data Availability Statement: The data presented in this study are available online.

Acknowledgments: Ken Barris is hereby acknowledged for his service as an English language editor for the manuscript.

Conflicts of Interest: The authors declare no conflict of interest.

\section{References}

1. Rex, J.; Dubé, S.; Krauskopf, P.; Berch, S. Investigating Potential Toxicity of Leachate from Wood Chip Piles Generated by Roadside Biomass Operations. Forests 2016, 7, 40. [CrossRef]

2. Svensson, H. Characterization, Toxicity and Treatment of Wood Leachate Generated Outdoors by The Wood-Based Industry. In Biology and Environmental Science; Linnaeus University Press: Småland, Sweden, 2014. Available online: http:/ /nu.diva-portal. org/smash/record.jsf?pid=diva2\%3A1089621\&dswid=1842 (accessed on 6 November 2020); ISBN 978-91-87427-86-2.

3. Taylor, B.R.; Goudey, J.S.; Carmichael, N.B. Toxicity of aspen wood leachate to aquatic life: Laboratory studies. Environ. Toxicol. Chem. 1996, 15, 150-159. [CrossRef]

4. Libralato, G.; Losso, C.; Ghirardini, A.V. Toxicity of untreated wood leachates towards two saltwater organisms (Crassostrea gigas and Artemia franciscana). J. Hazard. Mater. 2007, 144, 590-593. [CrossRef] [PubMed]

5. Hussain, A.; Dubey, S.K.; Kumar, V. Kinetic study for aerobic treatment of phenolic wastewater. Water Resour. Ind. 2015, 11, 81-90. [CrossRef]

6. Santos, B.A.Q. Continuous Bioremediation of Electroplating Effluent. In Chemical Engineering; Cape Peninsula University of Technology: Cape Town, South Africa, 2014. Available online: http://etd.cput.ac.za/handle/20.500.11838/865 (accessed on 6 November 2020).

7. Szymańska-Chargot, M.; Chylińska, M.; Gdula, K.; Kozioł, A.; Zdunek, A. Isolation and characterization of cellulose from different fruit and vegetable pomaces. Polymers 2017, 9, 495. [CrossRef]

8. Bensah, E.C.; Mensah, M. Chemical Pretreatment Methods for the Production of Cellulosic Ethanol: Technologies and Innovations. Int. J. Chem. Eng. 2013, 2013, 719607. [CrossRef]

9. Barana, D.; Salanti, A.; Orlandi, M.; Ali, D.S.; Zoia, L. Biorefinery process for the simultaneous recovery of lignin, hemicelluloses, cellulose nanocrystals and silica from rice husk and Arundo donax. Ind. Crops Prod. 2016, 86, 31-39. [CrossRef]

10. Pielhop, T.; Amgarten, J.; von Rohr, P.R.; Studer, M.H. Steam explosion pretreatment of softwood: The effect of the explosive decompression on enzymatic digestibility. Biotechnol. Biofuels 2016, 9, 152. [CrossRef]

11. O'Dwyer, J.; Walshe, D.; Byrne, K.A. Wood waste decomposition in landfills: An assessment of current knowledge and implications for emissions reporting. Waste Manag. 2018, 73, 181-188. [CrossRef]

12. Ravindran, R.; Jaiswal, A.K. A comprehensive review on pre-treatment strategy for lignocellulosic food industry waste: Challenges and opportunities. Bioresour. Technol. 2016, 199, 92-102. [CrossRef]

13. Zabed, H.; Sahu, J.N.; Boyce, A.N.; Faruq, G. Fuel ethanol production from lignocellulosic biomass: An overview on feedstocks and technological approaches. Renew. Sustain. Energy Rev. 2016, 66, 751-774. [CrossRef]

14. Passos, D.d.F.; Pereira, N.; Castro, A.M.d. A comparative review of recent advances in cellulases production by Aspergillus, Penicillium and Trichoderma strains and their use for lignocellulose deconstruction. Curr. Opin. Green Sustain. Chem. 2018, 14, 60-66. [CrossRef]

15. Leonowicz, A.; Matuszewska, A.; Luterek, J.; Ziegenhagen, D.; Wojtaś-Wasilewska, M.; Cho, N.S.; Hofrichter, M.; Rogalski, J. Biodegradation of lignin by white rot fungi. Fungal Genet. Biol. 1999, 27, 175-185. [CrossRef]

16. Angadam, J.O. Tertiary Biovalorisation of Grape Pomace; Cape Peninsula University of Technology: Cape Town, South Africa, 2018. Available online: https:/ / etd.cput.ac.za/handle/20.500.11838/2836 (accessed on 6 November 2020).

17. Ntwampe, S.K.O. Multicapillary Membrane Bioreactor Design; Cape Peninsula University of Technology: Cape Town, South Africa, 2005. Available online: http:/ / etd.cput.ac.za/handle/20.500.11838/897 (accessed on 6 November 2020).

18. Al-Kharousi, M.M.; Sivakumar, N.; Elshafie, A. Characterization of cellulase enzyme produced by Chaetomium sp. isolated from books and archives. EurAsian J. Biosci. 2015, 9, 52-60.

19. Jaeger, M. Study on Enzyme Activity of Nepenthesins in Carnivorous Nepenthes Alata; Max Planck Institute for Chemical Ecology: Thuringia, Germany, 2016.

20. Adibah, W.N.; Zakaria, W.; MohdAizat, W.; Goh, H.-H.; Noor, M.H. Proteomic analysis of pitcher fluid from Nepenthes ventrata. Data Brief 2018, 17, 517-519. 
21. Moran, J.A.; Clarke, C.M.; Hawkins, B.J. From Carnivore to Detritivore? Isotopic Evidence for Leaf Litter Utilization by the Tropical Pitcher Plant Nepenthes ampullaria. Int. J. Plant Sci. 2003, 164, 635-639. [CrossRef]

22. Dlangamandla, N.; Ntwampe, S.K.O.; Angadam, J.O.; Itoba-Tombo, E.F.; Chidi, B.S.; Mekuto, L. Integrated hydrolysis of mixed agro-waste for a second generation biorefinery using Nepenthes mirabilis pod digestive fluids. Processes 2019, 7, 64. [CrossRef]

23. Rottloff, S.; Miguel, S.; Biteau, F.; Nisse, E.; Hammann, P.; Kuhn, L.; Chicher, J.; Bazile, V.; Gaume, L.; Mignard, B.; et al. Proteome analysis of digestive fluids in Nepenthes pitchers. Ann. Bot. 2016, 117, 479-495. [CrossRef]

24. Growing Nepenthes Hydroponically: Preliminary Results 2016. 2021. Available online: https:/ / pitcherplants.proboards.com/ thread/13543/growing-nepenthes-hydroponically-preliminary-results (accessed on 6 November 2020).

25. Tayeb, A.H.; Amini, E.; Ghasemi, S.; Tajvidi, M. Cellulose nanomaterials-Binding properties and applications: A review. Molecules 2018, 23, 2684. [CrossRef]

26. Wang, Y.; Yuan, B.; Ji, Y.; Li, H. Hydrolysis of hemicellulose to produce fermentable monosaccharides by plasma acid. Carbohydr. Polym. 2013, 97, 518-522. [CrossRef]

27. Manavalan, T.; Liu, R.; Zhou, Z.; Zou, G. Optimization of acetyl xylan esterase gene expression in Trichoderma reesei and its application to improve the saccharification efficiency on different biomasses. Process Biochem. 2017, 58, 160-166. [CrossRef]

28. Yang, T.; Kumaran, J.; Li, X.; Amartey, S.A.; Maki, M.; Lu, F.; Qin, W. Chapter 5-Biofuels and Bioproducts Produced through Microbial Conversion of Biomass. In Bioenergy Research: Advances and Applications; Gupta, V.K., Tuohy, M.G., Kubicek, C.P., Saddler, J., Xu, F., Eds.; Elsevier: Amsterdam, The Netherlands, 2014; pp. 71-93.

29. Balat, M. Production of bioethanol from lignocellulosic materials via the biochemical pathway: A review. Energy Convers. Manag. 2011, 52, 858-875. [CrossRef]

30. Hasan, F.; Shah, A.A.; Hameed, A. Industrial applications of microbial lipases. Enzym. Microb. Technol. 2006, 39, $235-251$. [CrossRef]

31. Cheng, C.L.; Che, P.Y.; Chen, B.Y.; Lee, W.J.; YueLin, C.; Chang, J.S. Biobutanol production from agricultural waste by an acclimated mixed bacterial microflora. Appl. Energy 2012, 100, 3-9. [CrossRef]

32. Panagiotou, G.; Olsson, L. Effect of compounds released during pretreatment of wheat straw on microbial growth and enzymatic hydrolysis rates. Biotechnol. Bioeng. 2007, 96, 250-258. [CrossRef]

33. Wesenberg, D.; Kyriakides, I.; Agathos, S.N. White-rot fungi and their enzymes for the treatment of industrial dye effluents. Biotechnol. Adv. 2003, 22, 161-187. [CrossRef]

34. Carneiro, R.T.d.; Lopes, M.A.; Silva, M.L.C.; Santos, V.d.; de Souza, V.B.; de Sousa, A.O.; Pirovani, C.P.; Koblitz, M.G.B.; Benevides, R.G.; Góes-Neto, A. Trametes villosa lignin peroxidase (TvLiP): Genetic and molecular characterization. J. Microbiol. Biotechnol. 2017, 27, 179-188. [CrossRef]

35. Shaheen, R.; Asgher, M.; Hussain, F.; Bhattib, H.N. Immobilized lignin peroxidase from Ganoderma lucidum IBL-05 with improved dye decolorization and cytotoxicity reduction properties. Int. J. Biol. Macromol. 2017, 103, 57-64. [CrossRef]

36. Zhang, Y.-H.P.; Lynd, L.R. Toward an aggregated understanding of enzymatic hydrolysis of cellulose: Noncomplexed cellulase systems. Biotechnol. Bioeng. 2004, 88, 797-824. [CrossRef] [PubMed]

37. Danna, K. Controlled Production of Cellulases in Plants for Biomass Conversion. Annual Report, 11 March 1997-14 March 1998; Colorado University: Boulder, CO, USA, 1998.

38. Ali, S.; Mahmood, S. Mutagenesis of a thermophilic Alkalibacillus flavidus for anhanced production of an extracellular acetyl xylan esterase in semi-solid culture of linseed meal. Waste Biomass Valorization 2019, 11, 3327-3335. [CrossRef]

39. Olajide, A.; Adesina, F.C.; Onilude, A.A. A thermostable and alkalitolerant arabinofuranosidase by Streptomyces lividus. Biotechnol. J. Int. 2020, 24, 35-47. [CrossRef]

40. Pathania, S.; Sharma, N.; Verma, A.S.K. Optimization of cellulase-free xylanase produced by a potential thermoalkalophilic Paenibacillus sp. N1 isolated from hot springs of Northern Himalayas in India. J. Microbiol. Biotechnol. Food Sci. 2012, 2, 1-24.

41. Raza, A.; Bashir, S.; Tabassum, R. Statistical based experimental optimization for co-production of endo-glucanase and xylanase from Bacillus sonorensis BD92 with their application in biomass saccharification. Folia Microbiol. 2019, 64, 295-305. [CrossRef]

42. Regmi, S.; Choi, Y.S.; Kim, Y.K.; Khan, M.M.; Lee, S.H.; Cho, S.S.; Jin, Y.Y.; Lee, D.Y.; Yoo, J.C.; Suh, J.W. Endoglucanase produced by Bacillus subtilis strain CBS31: Biochemical characterization, thermodynamic study, enzymatic hydrolysis, and bio-industrial applications. Biotechnol. Bioprocess Eng. 2020, 25, 104-116. [CrossRef]

43. Mendoza, J.R.; Hernández, A.S.; Zúñiga, M.T.A.; Antón, M.G.; Osorio, G.A.; Lara, M.E.H. Purification and biochemical characterization of a novel thermophilic exo- $\beta-1,3$-glucanase from the thermophile biomass-degrading fungus Thielavia terrestris Co3Bag1. Electron. J. Biotechnol. 2019, 41, 60-71. [CrossRef]

44. Terrone, C.C.; Nascimento, J.M.d.; Terrasan, C.R.F.; Brienzo, M.; Carmonab, E.C. Salt-tolerant $\alpha$-arabinofuranosidase from a new specie Aspergillus hortai CRM1919: Production in acid conditions, purification, characterization and application on xylan hydrolysis. Biocatal. Agric. Biotechnol. 2020, 23, 101460. [CrossRef]

45. Xu, Z.; Wang, T.; Zhang, S. Extracellular secretion of feruloyl esterase derived from Lactobacillus crispatus in Escherichia coli and its application for ferulic acid production. Bioresour. Technol. 2019, 288, 121526. [CrossRef]

46. Park, Y.C.; Kim, J.S. Comparison of various alkaline pretreatment methods of lignocellulosic biomass. Energy 2012, 47, 31-35. [CrossRef]

47. Jönsson, L.J.; Martín, C. Pretreatment of lignocellulose: Formation of inhibitory by-products and strategies for minimizing their effects. Bioresour. Technol. 2016, 199, 103-112. [CrossRef] 
48. Taherzadeh, M.J.; Karimi, K. Pretreatment of lignocellulosic wastes to improve ethanol and biogas production: A review. Int. J. Mol. Sci. 2008, 9, 1621-1651. [CrossRef]

49. Limayem, A.; Ricke, S.C. Lignocellulosic biomass for bioethanol production: Current perspectives, potential issues and future prospects. Prog. Energy Combust. Sci. 2012, 38, 449-467. [CrossRef]

50. Nitsos, C.K.; Lazaridis, P.A.; Aigner, A.M.; Matis, K.A.; Triantafyllidis, K.S. Enhancing lignocellulosic biomass hydrolysis by hydrothermal pretreatment, extraction of surface lignin, wet milling and production of cellulolytic enzymes. ChemSusChem 2019, 12, 1179-1195. [CrossRef] [PubMed]

51. Jampatesh, S.; Sawisit, A.; Wong, N.; Jantama, S.S.; Jantama, K. Evaluation of inhibitory effect and feasible utilization of dilute acid-pretreated rice straws on succinate production by metabolically engineered Escherichia coli AS1600a. Bioresour. Technol. 2019, 273, 93-102. [CrossRef]

52. Van der Pol, E.C.; Bakker, R.R.; Baets, P.; Eggink, G. By-products resulting from lignocellulose pretreatment and their inhibitory effect on fermentations for (bio) chemicals and fuels. Appl. Microbiol. Biotechnol. 2014, 98, 9579-9593. [CrossRef]

53. Balan, V.; Sousa, L.D.C. De-Esterification of Biomass Prior to Ammonia Pretreatment and Systems and Products Related Thereto. U.S. Patent Application No. 20190010295, 7 June 2018.

54. Zhang, Y.; Huang, M.; Su, J.; Hu, H.; Yang, M.; Huang, Z.; Chen, D.; Wu, J.; Feng, Z. Overcoming biomass recalcitrance by synergistic pretreatment of mechanical activation and metal salt for enhancing enzymatic conversion of lignocellulose. Biotechnol. Biofuels 2019, 12, 12. [CrossRef]

55. Dabkowska, K.; Morales, M.A.; Kuglarz, M.; Angelidakib, I. Miscanthus straw as substrate for biosuccinic acid production: Focusing on pretreatment and downstream processing. Bioresour. Technol. 2019, 278, 82-91. [CrossRef]

56. Maddox, I.S.; Steiner, E.; Hirsch, S.; Wessner, S.; Gutierrez, N.A.; Gapes, J.R.; Schuster, K.C. The cause of "Acid Crash" and "Acidogenic Fermentations" during the batch acetone-butanol-ethanol (ABE-) fermentation process. J. Mol. Microbiol. Biotechnol. 2000, 2, 95-100.

57. Menon, V.; Rao, M. Trends in bioconversion of lignocellulose: Biofuels, platform chemicals and biorefinery concept. Prog. Energy Combust. Sci. 2012, 38, 522-550. [CrossRef]

58. Rawat, R.; Kumbhar, B.; Tewari, L. Optimization of alkali pretreatment for bioconversion of poplar (Populus deltoides) biomass into fermentable sugars using response surface methodology. Ind. Crops Prod. 2013, 44, 220-226. [CrossRef]

59. Amin, F.R.; Khalid, H.; Zhang, H.; Rahman, S.u.; Zhang, R.; Liu, G.; Chen, C. Pretreatment methods of lignocellulosic biomass for anaerobic digestion. AMB Express 2017, 7, 72. [CrossRef]

60. Nadir, N.; Ismail, N.L.; Hussain, A. Biomass for Bioenergy. In Fungal Pretreatment of Lignocellulosic Materials; Abomohra, A.E.-F., Ed.; InTech Open: Rijeka, Croatia, 2019. [CrossRef]

61. Barr, D.P.; Aust, S.D. Mechanisms white rot fungi use to degrade pollutants. Environ. Sci. Technol. 1994, 28, 78A-87A. [CrossRef]

62. Narayanaswamy, N.; Dheeran, P.; Verma, S.; Kumar, S. Biological Pretreatment of Lignocellulosic Biomass for Enzymatic Saccharification. In Pretreatment Techniques for Biofuels and Biorefineries; Fang, Z., Ed.; Springer: Berlin/Heidelberg, Germany, 2013; pp. 3-34.

63. Achinas, S.; Euverink, G.J.W. Theoretical analysis of biogas potential prediction from agricultural waste. Resour. Effic. Technol. 2016, 2, 143-147. [CrossRef]

64. Mithöfer, A. Carnivorous pitcher plants: Insights in an old topic. Phytochemistry 2011, 72, 1678-1682. [CrossRef]

65. Takeuchi, Y.; Chaffron, S.; Salcher, M.M.; Inatsugi, R.S.; Kobayashi, M.J.; Diway, B.; Mering, C.; Pernthaler, J.; Shimizu, K.K. Bacterial diversity and composition in the fluid of pitcher plants of the genus Nepenthes. Syst. Appl. Microbiol. 2015, 38, 330-339. [CrossRef]

66. Stephenson, P.; Hogan, J. Cloning and characterization of a ribonuclease, a cysteine proteinase, and an aspartic proteinase from pitchers of the carnivorous plant Nepenthes ventricosa Blanco. Int. J. Plant. Sci. 2006, 167, 239-248. [CrossRef]

67. Schulze, W.X.; Sanggaard, K.W.; Kreuzer, I.; Knudsen, A.D.; Bemm, F.; Thøgersen, I.B.; Bräutigam, A.; Thomsen, L.R.; Schliesky, S.; Dyrlund, T.F.; et al. The protein composition of the digestive fluid from the venus flytrap sheds light on prey digestion mechanisms. Mol. Cell. Proteom. 2012, 11, 1306-1319. [CrossRef]

68. Kumar, P.; Barrett, D.M.; Delwiche, M.J.; Stroeve, P. Methods for pretreatment of lignocellulosic biomass for efficient hydrolysis and biofuel production. Ind. Eng. Chem. Res. 2009, 48, 3713-3729. [CrossRef]

69. Higashi, S.; Nakashima, A.; Ozaki, H.; Abe, M.; Uchiumi, T. Analysis of feeding mechanism in a pitcher of Nepenthes hybrida. J. Plant. Res. 1993, 106, 47-54. [CrossRef]

70. Bornscheuer, U.T.; Ordoñez, G.R.; Hidalgo, A.; Gollina, A.; Lyon, J.; Hitchman, T.S.; Weiner, D.P. Selectivity of lipases and esterases towards phenol esters. J. Mol. Catal. B Enzym. 2005, 36, 8-13. [CrossRef]

71. Maroušek, J.; Bartoš, P.; Filip, M.; Kolár, L.; Konvalina, P.; Maroušková, A.; Moudrý, J.; Peterka, J.; Šál, J.; Šoch, M.; et al. Advances in the agrochemical utilization of fermentation residues reduce the cost of purpose-grown phytomass for biogas production. In Energy Sources, Part A: Recovery; Taylor \& Francis: Philadelphia, PA, USA, 2020.

72. Maroušek, J.; Myšková, K.; Žák, J. Managing environmental innovation: Case study on biorefinery concept. Rev. Técnica Fac. Ing. Univ. Zulia 2015, 38, 216-220. 